\title{
Cooking can decrease mercury contamination of a mushroom meal: Cantharellus cibarius and Amanita fulva
}

\author{
Jerzy Falandysz ${ }^{1}$ (D) Malgorzata Drewnowska ${ }^{1}$
}

Received: 28 December 2016/Accepted: 23 March 2017 / Published online: 6 April 2017

(C) The Author(s) 2017. This article is published with open access at Springerlink.com

\begin{abstract}
Mushrooms (Cantharellus cibarius and Amanita fulva) were blanched (parboiled) and pickled using different treatment conditions with the aim of carrying out the study into effect on removal of toxic mercury $(\mathrm{Hg})$ accumulated in flesh. Blanching of fresh sliced C. cibarius caused leaching of Hg by approximately $15 \%$, while loss of up to $35 \%$ was observed for sliced, deep-frozen fruit bodies. The rate of $\mathrm{Hg}$ leaching from the $C$. cibarius in practice was the same when blanched for 5 or $15 \mathrm{~min}$ irrespective of potable or deionized water used. Pickling of blanched C. cibarius with a diluted vinegar marinade had only a minor, if any, effect on removal of $\mathrm{Hg}$ and was without effect on blanched caps of A. fulva . Mercury was better extracted by boiling water from the fresh caps of A. fulva ( $56 \pm 2 \%$ of the initial level in fresh caps) than from the fresh or frozen fruit bodies of $C$. cibarius. Total leaching rate of $\mathrm{Hg}$ from a pickled C. cibarius when fresh fruit bodies were processed was between $15 \pm 5$ and $37 \pm 7 \%$ (median range 13-34\%), and when deep-frozen fruit bodies were processed, it was between $37 \pm 7$ and $39 \pm 8 \%$ (median range 34-39\%). Pickling of the caps of A. fulva with diluted vinegar did not increase leaching of $\mathrm{Hg}$. Blanching of mushrooms before future culinary use is a simple procedure recommended in reduction of contamination with $\mathrm{Hg}$ of cooked mushroom meal. Pickling had little if any effect on further removal of $\mathrm{Hg}$ from the initially blanched mushrooms.
\end{abstract}

Responsible editor: Philippe Garrigues

Jerzy Falandysz

jerzy.falandysz@ug.edu.pl

1 Laboratory of Environmental Chemistry and Ecotoxicology, Gdańsk University, 63 Wita Stwosza Str, 80-308 Gdańsk, PL, Poland
Keywords Hazard decrease $\cdot$ Household treatment . Mercury $\cdot$ Mushrooms $\cdot$ Pollution

\section{Introduction}

Mushrooms foraged from the wild are traditional and popular organic food, which is considered rich in macro- and microelements and different organic compounds of nutritional and medicinal properties (Kalač 2016). They are valued by many around the world, while accessibility to good foraging areas, gourmet recipes and tradition, and intake per capita highly vary in regions of the world (Wang et al. 2014; Zhang et al. 2010). Estimated maximum intake is up to $20 \sim 30 \mathrm{~kg}$ fresh biomass per capita annually for the locals in Yunnan, China (Zhang et al. 2010).

The terrestrial mushrooms both saprobes and ectomycorrhizal due to specificities in their physiology may efficiently take-up from a polluted environment and accumulate in flesh different toxic chemical elements, e.g., $\mathrm{Cd}$ and $\mathrm{Hg}$ (Brzostowski et al. 2011; Falandysz et al. 2017; Gabriel et al. 2016; Kalač 2016). Mercury (Hg) is one of the metallic elements undesired in water media, human foods, and animal feeds, which as an environmentally hazardous compound is well accumulated in the fruit bodies by various species of mushrooms (Árvay et al. 2014; Falandysz 2016, 2017; Nasr and Arp 2011; Širić et al. 2017). Apart from an anthropogenic pollution with $\mathrm{Hg}$, mushrooms can accumulate this element at great concentration also when grew in soils rich in geogenic $\mathrm{Hg}$ where bedrock is naturally enriched in $\mathrm{Hg}$ because of a geochemical anomalies (Kojta et al. 2015).

Cooking and industrial processing of mushrooms can have a pronounced impact on content and composition of compounds in a mushroom meals but the data are generally limited for $\mathrm{Hg}$ or a wide spectrum of the metallic elements and 
metalloids (Biekman et al. 1996; Coskuner and Özdemir 1997; Svoboda et al. 2002; Vetter 2003, Źrodlowski 1995). Recently, a polystyrene-g-2-adenine chelating resin was developed and used to preconcentrate and detect the concentration of $\mathrm{Hg}$ ions in edible mushrooms ( $\mathrm{Li}$ et al. 2016) or selective removal of copper with polystyrene-1,3-diaminourea chelating resin (Shen et al. 2016), which technologies in principle is without any future in application for foods.

Mushrooms can be cooked in different manner, and the cooking books gave many recipes. Some of the treatments are of more general or universal nature, e.g., a short time (5$15 \mathrm{~min}$ ) boiling (blanching; parboiling) or boiling for a longer time, while other can be specific for a species of mushroom or a dish. Blanching is a radical manner, because of excess of boiling water used, which causes fruit body dehydration and shrinkage, and denaturation, hydrolysis, and dissolution of the building and other organic constituents of mushroom. Blanching efficiently removes hazardous constituents such as alkali element — radiocaesium $\left({ }^{137} \mathrm{Cs}\right)$ - from contaminated mushrooms (Skibniewska and Smoczyński 1999). Blanching also significantly removes from mushrooms many bio-elements, which was little studied so far, while apart from radiocaesium, it can also decrease content of the toxic metallic contaminants such as cadmium $(\mathrm{Cd})$, lead $(\mathrm{Pb})$, and $\mathrm{Hg}$ (Svoboda et al. 2002). This study investigates the potential effect of blanching and pickling in removal of $\mathrm{Hg}$ from a whole fruit bodies of chanterelle $C$. cibarius Fr. and from the caps of tawny grisette with current name in Latin as A. fulva Fr., and several synonyms: Agaricus fulvus Schaeff., A. fulvaf. alba (Courtec.), Amanita vaginata var. fulva (Fr.) Gillet, Amanitopsis fulva (Fr.), Amanitopsis fulva F. alba Courtec., Amanitopsis fulva (Fr.) W.G. Sm., Amanitopsis vaginata var. fulva (Fr.) Sacc., and Vaginata fulva (Fr.) A.H. Sm. (Species Fungorum 2017).

Blanching of $C$. cibarius and other mushrooms before further cooking (common frying, frying with eggs, freezing, and further frying with eggs or stewing, using for soup or pickling) is common procedure in the Polish kitchen.

\section{Materials and methods}

\section{Mushrooms and other products}

Five sets of matured fruit bodies of $C$. cibarius samples (from 267 to 358 fruit bodies in a pool per site) and one set of 60 matured fruit bodies of $A$. fulva (only caps selected) were used in the study. $C$. cibarius were collected from five background (unpolluted) areas: (i) forest near the Jastrzębia Góra, coordinates $54.8312^{\circ} \mathrm{N}, 18.3129^{\circ} \mathrm{E}$; (ii) Lapino, coordinates $54.3000^{\circ} \mathrm{N}, 18.4333^{\circ} \mathrm{E}$; (iii) Kościerzyna forests, coordinates $54.0415^{\circ} \mathrm{N}, 18.2392^{\circ} \mathrm{E}$; (iv) the Darżlubska Wilderness, coordinates $54.6747^{\circ} \mathrm{N}, 18.2577^{\circ} \mathrm{E}$; and (v) Tucholskie
Pinewoods, coordinates $53.8152^{\circ} \mathrm{N}, 17.5648^{\circ} \mathrm{E}$ in the north-central region of Poland in 2012-2014. A. fulva was collected from a forest nearby to the location Łapino (coordinates $54.3000^{\circ} \mathrm{N}, 18.4333^{\circ} \mathrm{E}$ ) in the Kolbudy Forest Inspectorate of Pomerania in 2011.

Fruit bodies of $C$. cibarius were, in aim of the removal of adhering debris, rinsed with cold tap water and drained. Next, each fruit body in a sample set was divided into four or three parts (vertical cuts using a plastic knife), which were pooled and further subsampled and treated accordingly - dried, frozen, blanched, and blanched/pickled (Table 1). The caps of A. fulva were in situ cleaned from any adhering foreign debris. Next, they were divided into quadrants, which were pooled (four samples) and further divided for a subsamples and treated accordingly (Table 1 ).

Deionized water free of $\mathrm{Hg}$, potable bottled water (Fonte spring from the location Nieszawa in Poland) free of $\mathrm{Hg}$, and commercial spirit vinegar were used as media in the blanching and pickling experiments. The spirit vinegar (10\% acetic acid solution) free of $\mathrm{Hg}\left(<5 \mathrm{ng} \mathrm{L}^{-1}\right)$ in glass bottle $(0.5 \mathrm{~L})$ with an aluminum screw cap and polyethylene gasket used for preparation of marinade was bought in a grocery shop.

\section{Conventional drying}

From each sample set of a freshly sliced fruit bodies or caps, the subsamples were selected. They were placed into plastic trays of an electrically heated commercial dryer (dehydrator for vegetables; model MSG-01; MPM Product, Milanówek, Poland) and dried at $65{ }^{\circ} \mathrm{C}$ to constant mass. Dried fungal materials were ground using a porcelain pestles and mortars that were cleaned by hand washing using laboratory brush, deionized water, and detergent, and further rinsed with distilled water and dried in an electrically heated laboratory dryer at $105{ }^{\circ} \mathrm{C}$. Ground fungal materials were transferred into a screw-capped plastic tubes (VWR®, Ultra High Performance, $15 \mathrm{~mL}$ ) and closed, and the tubes were packed into polyethylene bags and kept sealed in dry and clean condition in a storage room until analysis. Dried and ground fungal materials were considered as the reference samples for $\mathrm{Hg}$ determinations.

\section{Deep freezing}

Two subsamples of $C$. cibarius were further divided into portions and kept frozen at $-20{ }^{\circ} \mathrm{C}$ for 1 month. The subsamples of the frozen mushrooms were freeze dried (lyophilizer model LYOVAC GT2; Steris, Germany). The freeze-dried mushrooms were ground in the same way as those which were dried conventionally and, in a form of a powder, were further transferred into a screw-capped plastic tubes, which were kept closed in sealed polyethylene bags until analysis. 
Table 1 Data on mercury concentrations ( $\mathrm{mg} \mathrm{kg}^{-1}$ dry biomass) and mercury leaching rate (\%) from household treated C. cibarius and A. fulva

\begin{tabular}{|c|c|c|c|c|c|c|c|}
\hline \multirow[t]{2}{*}{ Parameter } & \multirow{2}{*}{$\begin{array}{l}\text { Species } \\
\text { Sample size } \\
\text { Status }\end{array}$} & \multicolumn{5}{|l|}{ C. cibarius } & \multirow{2}{*}{$\begin{array}{l}\text { A. fulva } \\
4(60) \\
\text { Fresh }\end{array}$} \\
\hline & & $\begin{array}{l}7(311)^{\mathrm{a}} \\
\text { Fresh }\end{array}$ & $\begin{array}{l}7(267) \\
\text { Fresh }\end{array}$ & $\begin{array}{l}7(331) \\
\text { Fresh }\end{array}$ & $\begin{array}{l}8(358) \\
\text { Deep frozen }\end{array}$ & $\begin{array}{l}7(298) \\
\text { Deep frozen }\end{array}$ & \\
\hline \multirow[t]{6}{*}{$\mathrm{Hg}$} & Mean \pm S.D. & $0.032 \pm 0.004$ & $0.017 \pm 0.003$ & $0.034 \pm 0.011$ & $0.041 \pm 0.011$ & $0.033 \pm 0.009$ & $0.23 \pm 0.02$ \\
\hline & Range & $0.027-0.037$ & $0.013-0.021$ & $0.027-0.053$ & $0.032-0.057$ & $0.022-0.050$ & $0.21-0.25$ \\
\hline & Median & 0.030 & 0.017 & 0.028 & 0.035 & 0.031 & 0.22 \\
\hline & Treatment & Blanching & Blanching & Blanching & Blanching & Blanching & Blanching \\
\hline & Water & Potable & Potable & Deionized & Potable & Deionized & Deionized \\
\hline & Time (min) & 5 & 15 & 15 & 15 & 15 & 15 \\
\hline \multirow[t]{3}{*}{$\mathrm{Hg}$} & Mean \pm S.D. & $0.028 \pm 0.003$ & $0.015 \pm 0.003$ & $0.030 \pm 0.009$ & $0.027 \pm 0.006$ & $0.021 \pm 0.006$ & $0.099 \pm 0.010$ \\
\hline & Range & $0.023-0.031$ & $0.012-0.019$ & $0.024-0.045$ & $0.021-0.036$ & $0.015-0.033$ & $0.087-0.11$ \\
\hline & Median & 0.027 & 0.014 & 0.026 & 0.024 & 0.021 & 0.098 \\
\hline \multirow{4}{*}{$\begin{array}{l}\text { Loss vis. fresh } \\
\text { or deep-frozen mushrooms (\%) }\end{array}$} & Mean \pm S.D. & $13 \pm 5$ & $13 \pm 5$ & $12 \pm 2$ & $33 \pm 6$ & $36 \pm 6$ & $56 \pm 2$ \\
\hline & Range & $9.0-20$ & $8.0-22$ & $9.0-15$ & $20-43$ & $31-50$ & $55-58$ \\
\hline & Median & 10 & 11 & 11 & 34 & 34 & 56 \\
\hline & Treatment & Pickling ${ }^{\mathrm{b}}$ & Pickling & Pickling & Pickling & Pickling & Pickling \\
\hline \multirow[t]{3}{*}{$\mathrm{Hg}$} & Mean \pm S.D. & $0.025 \pm 0.002$ & $0.014 \pm 0.003$ & $0.029 \pm 0.007$ & $0.025 \pm 0.004$ & $0.020 \pm 0.005$ & $0.11 \pm 0.01$ \\
\hline & Range & $0.022-0.028$ & $0.0095-0.018$ & $0.023-0.041$ & $0.021-0.032$ & $0.015-0.030$ & $0.10-0.13$ \\
\hline & Median & 0.024 & 0.013 & 0.026 & 0.023 & 0.019 & 0.11 \\
\hline \multirow{3}{*}{$\begin{array}{l}\text { Loss vis. blanched mushrooms } \\
\text { (\%) }\end{array}$} & Mean \pm S.D. & $10 \pm 7^{\mathrm{c}}$ & $8.0 \pm 6.4^{\mathrm{d}}$ & $4.2 \pm 3.7^{\mathrm{e}}$ & $6.7 \pm 7.1^{\mathrm{f}}$ & $8.5 \pm 9.3^{\mathrm{g}}$ & 0 \\
\hline & Range & $0-22$ & $0-18$ & $0-9.6$ & $0-18$ & $0-24$ & 0 \\
\hline & Median & 9.0 & 6.7 & 3.9 & 6.2 & 7.8 & 0 \\
\hline \multirow[t]{3}{*}{ Total loss (\%) } & Mean \pm S.D. & $21 \pm 6$ & $19 \pm 7$ & $15 \pm 5$ & $37 \pm 7$ & $39 \pm 8$ & $50 \pm 3$ \\
\hline & Range & $16-29$ & $10-33$ & $7.0-22$ & $29-49$ & $29-50$ & $47-53$ \\
\hline & Median & 22 & 18 & 13 & 34 & 39 & 51 \\
\hline
\end{tabular}

${ }^{\mathrm{a}}$ Number of composite samples and total number of fruiting bodies/caps (in parentheses)

${ }^{\mathrm{b}}$ Blanched mushrooms were pickled

${ }^{\mathrm{c}}$ In one sample, an increase by $3 \%$

${ }^{\mathrm{d}}$ In one sample, an increase by $4 \%$

${ }^{\mathrm{e}}$ In two samples, an increase by 2 and $3 \%$

${ }^{\mathrm{f}}$ In one sample, an increase by $3 \%$

${ }^{\mathrm{g}}$ In three samples, an increase by 4,5 , and $21 \%$

\section{Blanching}

Fresh or frozen sliced fruit bodies or caps were blanched respectively for 5 to $15 \mathrm{~min}$ in gently boiling deionized water $(150 \mathrm{~mL})$ in a glass beakers or in potable water in a stainless steel pot. The ratio of the mushroom matter to water was 1:5 $(w / w)$. The blanched mushrooms were next drained using plastic colander, freeze dried, ground, transferred into a screw-capped plastic tubes, and kept for further analyses or were pickled to examine impact of pickling (Table 1).

\section{Pickling}

Freshly blanched $C$. cibarius and A. fulva samples directly after draining were pickled using a vinegar-based marinade. Marinade was made by dilution of vinegar with tap or deionized water in proportion 1: 4. Mushrooms were pickled in glass beakers $(150 \mathrm{~mL})$. Beakers filled with mushrooms and marinade were tightly sealed with a plastic foil from the top and kept in room temperature for 1 month. Next, mushrooms were drained and subsamples were freeze dried and ground, using porcelain pestle and mortar, and powdered samples were packed into a screw-capped plastic tubes (VWR $®$, Ultra High Performance, $15 \mathrm{~mL}$ ). Tubes were further packed into a foil bag, which was sealed, and kept until analysis in dry and clean condition in a storage room.

\section{Mercury analysis}

The reagents used in this study were of analytical reagent grade. Deionized water was used for the preparation of the solutions. Mercury standard solution of $1.0 \mathrm{mg} \mathrm{mL}^{-1}$ was 
obtained from the $10 \mathrm{mg} \mathrm{mL}^{-1}$ standard stock solution. Blanks and $3,5,10,15$, and $20 \mu \mathrm{L}$ (low mode) and 25, 50, 100, 150, and $200 \mu \mathrm{L}$ (high mode) of $1.0 \mathrm{mg} \mathrm{mL}^{-1} \mathrm{Hg}$ standard solutions were injected into the analyzer for the construction of calibration curves.

Mercury content of all fungal and blank samples was determined using cold-vapor atomic absorption spectroscopy (CV-AAS) by a direct sampled material thermal decomposition coupled with gold wool trap of $\mathrm{Hg}$ vapors and its further desorption and quantitative measurement at wavelength of $253.7 \mathrm{~nm}$. The analytical instrument used was mercury analyzer (MA-2000, Nippon Instruments Corporation, Takatsuki, Japan) equipped with autosampler and operated respectively at low (3 to $20 \mathrm{ng} \mathrm{Hg}$ per sample) and high ( 25 to $150 \mathrm{ng} \mathrm{Hg}$ per sample) mode (Falandysz et al. 2012).

Analytical control and assurance quality (AC/AQ) was assessed through analysis of blank samples and two certified reference materials: CS-M-2 (dried mushroom powder Agaricus campestris for which declared $\mathrm{Hg}$ content was $0.164 \pm 0.004 \mathrm{mg} \mathrm{kg}^{-1} \mathrm{dm}$ ) and CS-M-4 (dried mushroom powder Leccinum scabrum for which declared content was $0.465 \pm 0.024 \mathrm{mg} \mathrm{kg}^{-1} \mathrm{db}$ ) - both produced by the Institute of Nuclear Chemistry and Technology, Warsaw, Poland. Our result for CS-M-2 was $0.164 \pm 0.006 \mathrm{mg} \mathrm{kg}^{-1} \mathrm{db}(n=6$; mean recovery $101 \%$ ) and for CS-M4 was $0.448 \pm 0.010 \mathrm{mg} \mathrm{kg}^{-1}$ $\mathrm{db}(n=6$; mean recovery 98\%).

\section{Results and discussion}

\section{Fresh mushrooms}

Mercury concentrations in the composite samples of C. cibarius subjected for a household treatment were from $0.017 \pm 0.003$ to $0.041 \pm 0.011 \mathrm{mg} \mathrm{kg}^{-1}$ dry biomass $(\mathrm{db})$ on the average, and total range was $0.013-0.057 \mathrm{mg} \mathrm{kg}^{-1} \mathrm{db}$ (Table 1). The results showed on a small contamination of C. cibarius with $\mathrm{Hg}$, while the values agreed with data reported for this species foraged from the background forested areas in Poland (Falandysz et al. 2012).

Mercury concentration in A. fulva was at $0.23 \pm 0.02 \mathrm{mg} \mathrm{kg}^{-1}$ $\mathrm{db}$ (Table 1). This result agreed with the values reported for A. fulva foraged across Poland and also with data for Amanita vaginata (Bull.) Lam., which is a mushroom from the same section as A. fulva (Drewnowska et al. 2014; Falandysz and Drewnowska 2015).

\section{Blanched mushrooms}

Fresh fruit bodies of $C$. cibarius when blanched for 5 or $15 \mathrm{~min}$ in potable or deionized water dropped $\mathrm{Hg}$ concentration by $12 \pm 2$ to $13 \pm 5 \%$ (total range $8.0-22 \%$ ). Fruit bodies which were initially deep frozen and further blanched dropped
Hg by $33 \pm 6$ to $36 \pm 6 \%$ (total range $20-50 \%$ ). Fresh caps of A. fulva during blanching for $15 \mathrm{~min}$ dropped $\mathrm{Hg}$ concentration from $0.23 \pm 0.02$ to $0.098 \pm 0.010 \mathrm{mg} \mathrm{kg}^{-1} \mathrm{db}$ - decrease by $56 \pm 2 \%$ (Table 1 ).

The rates of $\mathrm{Hg}$ leaching from C. cibarius were in practice the same when blanched for 5 or $15 \mathrm{~min}$ and in potable or deionized water. A rate of $\mathrm{Hg}$ leaching from the caps of A. fulva was higher than the $10 \%$ drop reported for halves of a whole fruit bodies of this mushroom blanched for $10 \mathrm{~min}$ in boiled tap water (rich in calcium) (Falandysz and Drewnowska 2015).

Clearly, in the blanching experiments performed in this study, it was harder to remove $\mathrm{Hg}$ sequestered in flesh by C. cibarius than that from the quadrants of the caps of A. fulva. Results on the leaching rates of $\mathrm{Hg}$ obtained in this study were roughly similar with those reported from the experiments with blanched mushroom Imleria badia (Fr.) Vizzini (former name Xerocomus badius (Fr.) E.-J. Gilbert). Namely, sliced fresh fruit bodies of the I. badia when blanched in the salted water for $15 \mathrm{~min}$ lost $15 \%$ of $\mathrm{Hg}$, while when were blanched a deep frozen mushrooms, a drop of $\mathrm{Hg}$ was $\sim 22 \%$ (Svoboda et al. 2002).

\section{Pickled mushrooms}

Samples of blanched mushrooms from the particular experiments were also pickled under conditions given in previous section. Pickling is a common household treatment for C. cibarius and caps of A. fulva. When mushrooms are prepared for home use or commerce, they can be pickled in a vinegar-based marinade alone or with added table salt, carrot, onion, and spices. No salt, vegetables, or species were added to marinade in this study.

Pickling had only a minor effect or was without effect on leaching of $\mathrm{Hg}$ from the blanched mushrooms. In the case of C. cibarius, some portion of $\mathrm{Hg}$ leached out of the sliced fruit bodies, e.g., by around 2-3\%, while for some samples, there was no leaching but a slight increase in $\mathrm{Hg}$ content (when data were normalized to dry biomass content). A reason for lack of decrease of $\mathrm{Hg}$ content in blanched fungal material when they were pickled can be a selective leakage of some organic compounds free or with low content of $\mathrm{Hg}$ but in parallel was no leaching or only a weak leaching of $\mathrm{Hg}$. This can result in a slight increase in content of the elements $(\mathrm{Hg})$ which does not leach or leach in lower rates than the bulk organic materials of the fruit bodies. No loss of $\mathrm{Hg}$ from the caps was noted for pickled A. fulva when related to the blanched caps (Table 1).

In this study, fresh and sliced fruit bodies of $C$. cibarius when blanched lost on average $36 \%$ of biomass, while when they were further pickled, they lost in total $40 \%$ of the original biomass. Frozen C. cibarius when blanched lost $62 \%$ of biomass, while when further pickled, lost $74 \%$ of biomass. Blanching of Agaricus bisporus (J.E. Lange) Imbach caused 
a decrease of the biomass of the fruit bodies by $30 \%$ due to a partial loss of water and water soluble constituents, while for Grifola frondosa (Dicks.) Gray and Flammulina velutipes (Curtis) Singer, decrease was in the range 11-16\% (Dikeman et al. 2005).

Total leaching rate of $\mathrm{Hg}$ for C. cibarius was between $15 \pm 5$ and $21 \pm 6 \%$ when fresh mushrooms were treated (blanched and pickled) and between $37 \pm 7$ and $39 \pm 8 \%$ when frozen mushrooms were treated. For blanched or blanched and pickled caps of A. fulva, drop of $\mathrm{Hg}$ was between $50 \pm 3$ and $56 \pm 2 \%$.

This is known that radiocaesium and some other compounds leak out of the fruit bodies at higher rate when the fungal cells were more or less broken, because of a specific treatment of fruit bodies, which were deep frozen, sliced, or powdered than a whole fresh or a little defragmented (sliced) fruit bodies (Kenigsberg et al. 1996; Svoboda et al. 2002). An observed difference in the leaking rates of $\mathrm{Hg}$ between C. cibarius and A. fulva can be also because of a difference in the texture of the flesh of the fruit body between both species, which is more fleshy and firm for $C$. cibarius while much more fragile and softer for A. fulva.

Mercury in champignon A. bisporus cultivated in compost fortified with $\mathrm{Hg}$ salt $\left({ }^{203} \mathrm{Hg}\right)$ was noted to be bound largely in high-molecular-mass proteins, and oyster mushroom Pleurotus ostreatus was in protein fraction of $17-45 \mathrm{kDa}$ (Lasota and Florczak 1991). Evidently, during blanching of I. badia, Hg leached at much lower degree than radiocaesium $\left({ }^{137} \mathrm{Cs}\right)$ (Skibniewska and Smoczyński 1999; Svoboda et al. 2002). Radiocaesium ${ }^{137} \mathrm{Cs}$ and ${ }^{134} \mathrm{Cs}$ (and stable caesium, ${ }^{133} \mathrm{Cs}$ ) forms weaker bonds in salts and can be largely in protoplasm than other parts of the cells in the fruit bodies, while not in proteins like is an inorganic Hg. Inorganic Hg is a major (> $90 \%$, on the average) $\mathrm{Hg}$ compound in mushrooms. Mercury can form more firm bonds than caesium and especially with sulfhydryl groups of proteins or can form other sparklingly soluble and more difficult for leaching compounds in mushrooms.

Summing up, the Hg was better extracted by boiling water from the caps of $A$. fulva than from the fruit bodies of C. cibarius. Blanching of fresh and sliced fruit bodies of C. cibarius caused leakage of $\mathrm{Hg}$ by around $15 \%$, while blanching of deep-frozen and sliced fruit bodies caused leakage of $\mathrm{Hg}$ by around $35 \%$. The rate of $\mathrm{Hg}$ leaching from the C. cibarius in practice was the same when blanched for 5 or 15 min irrespective of potable or deionized water used. Blanching of the quadrants of fresh caps of the A. fulva causes loss of $\mathrm{Hg}$ by around $56 \%$. Pickling had only little impact if any on leaching of $\mathrm{Hg}$ from the blanched fruit bodies of C. cibarius or caps of A. fulva. Lack of any significant leaching of $\mathrm{Hg}$ from the blanched mushrooms when pickled using diluted vinegar can imply on its occurrence in mushrooms large in form of a sparklingly soluble compounds of a type $\mathrm{HgSe}, \mathrm{HgS}$ and//or bonds with sulphydryl groups $(-\mathrm{SH})$ in macromolecules (proteins), which were not degraded and leached by boiling water. These compounds can be weakly leachable from pickled mushrooms in human gut, while blanching can remove from the fruit bodies a large portion of $\mathrm{Hg}$ attached with soluble or colloidal fractions of the flesh which can be discarded with the waste water. Hence, in practice, blanching of mushrooms before future culinary use is a simple procedure recommended in reduction of $\mathrm{Hg}$ contamination in foraged and cultivated mushrooms and which can be good also for mushrooms harvested from grounds subjected for mycoremediation because of $\mathrm{Hg}$ pollution. Pickling had little if any effect on further removal of $\mathrm{Hg}$ from the initially blanched mushrooms.

Acknowledgements This study in part was financially supported to by the National Science Centre of Poland under call PRELUDIUM (Project no DEC-2012/05/N/NZ9/01561).

Open Access This article is distributed under the terms of the Creative Commons Attribution 4.0 International License (http:// creativecommons.org/licenses/by/4.0/), which permits unrestricted use, distribution, and reproduction in any medium, provided you give appropriate credit to the original author(s) and the source, provide a link to the Creative Commons license, and indicate if changes were made.

\section{References}

Árvay J, Tomáša J, Hauptvogl M, Kopernická M, Kováčik A, Bajčan D, Massányi P (2014) Contamination of wild-grown edible mushrooms by heavy metals in a former mercury-mining area. J Environ Sci Health Part B 49:815-827

Biekman ESA, Kroese-Hoedeman HI, Schijven HPHM (1996) Loss of solutes during blanching of mushrooms (Agaricus bisporus) as a result of shrinkage and extraction. J Food Eng 28:139-152

Brzostowski A, Jarzyńska G, Kojta AK, Wydmańska D, Falandysz J (2011) Variations in metal levels accumulated in Poison Pax (Paxillus involutus) mushroom collected at one site over four years. J Environ Sci Health Part A 46:581-588

Coskuner Y, Özdemir Y (1997) Effect of canning processes on the elements content of cultivated mushrooms (Agaricus bisporus). Food Chem 60:559-562

Dikeman CL, Bauer LL, Flickinger EA, Fahey GC Jr (2005) Effects of stage of maturity and cooking on the chemical composition of select mushroom varieties. J Agric Food Chem 53:1130-1138

Drewnowska M, Nnorom IC, Falandysz J (2014) Mercury in the Tawny Grisette, Amanita vaginata Fr. and soil below the fruiting bodies. J Environ Sci Health Part B 49:521-526

Falandysz J (2016) Mercury bio-extraction by fungus Coprinus comatus: a possible bioindicator and mycoremediator of polluted soils. Environ Sci Poll Res 23:7444-7451

Falandysz J (2017) Mercury accumulation of three Lactarius mushroom species. Food Chem 214:96-101

Falandysz J, Drewnowska M (2015) Distribution of mercury in Amanita fulva (Schaeff.) Secr. mushrooms: accumulation, loss in cooking and dietary intake. Ecotox Environ Saf 115:49-54

Falandysz J, Widzicka E, Kojta AK, Jarzyńska G, Drewnowska M, Dryżałowska A, Danisiewicz-Czupryńska D, Lenz E, Nnorom IC (2012) Mercury in common chanterelles mushrooms: Cantharellus spp. update. Food Chem 133:842-850 
Falandysz J, Chudzińska M, Hanć A, Barałkiewicz D, Drewnowska M (2017) Toxic elements and bio-metals in Cantharellus mushrooms from Poland and China. Environ Sci Pollut Res 24. doi:10.1007/ s11356-017-8554-Z

Gabriel J, Švec K, Kolihová K, Tlustoš P, Száková J (2016) Translocation of mercury from substrate to fruit bodies of Panellus stipticus, Psilocybe cubensis, Schizophyllum commune and Stropharia rugosoannulata on oat flakes. Ecotox Environl Saf 125:184-189

Kalač P (2016) Edible mushrooms, chemical composition and nutritional value. Academic Press, London

Kenigsberg J, Belli M, Tikhomirov F, Buglova E, Shevchuk V, Renaudd $\mathrm{Ph}$, Maubertd H, Bruke G, Shutov V (1996) Exposures from consumption of forest produce. (Eds) A. Karaoglou, G. Desmet, G. N. Kelly, H. G. Menzel. The radiological consequences of the Chernobyl accident: proceedings of the first international conference Minsk, Belarus 18 to 22 march 1996 European Commission and the Belarus, Russian and Ukrainian Ministries on Chernobyl Affairs, Emergency Situations and Health, EUR 16544 EN, Published by the EUROPEAN COMMISSION Directorate-General XII Science, Research and Development, B-1049 Brussels pp. 271-281 in

Kojta AK, Wang Y, Zhang J, Li T, Saba M, Falandysz J (2015) Mercury contamination of fungi genus Xerocomus in the Yunnan Province in China and the region of Europe. J Environ Sci Health Part A 50: $1342-1350$

Lasota W, Florczak J (1991) Effect of growing conditions on accumulation of some toxic substances in mushrooms. II. Absorption and binding of $203 \mathrm{Hg}$ by Agaricus bisporus Lange and Pleurotus ostreatus Jacq. Fr. Kumm. (in Polish). Bromatol Chem Toksykol 24:67-71

Li S, Feng Y, Fang L, Zheng X, Chen D, Yao L, Xiong C (2016) Synthesis and characterization of a novel chloromethylated polystyrene-g-2-adenine chelating resin and its application to preconcentrate and detect the concentration of mercury ions in edible mushroom samples. Canadian J Chem 94:751-758

Nasr M, Arp PA (2011) Hg concentrations and accumulations in fungal fruiting bodies, as influenced by forest soil substrates and moss carpets. Appl Geochem 26:1905-1917

Shen C, Chang Y, Fang L, Min M, Xiong CH (2016) Selective removal of copper with polystyrene-1,3-diaminourea chelating resin: synthesis and adsorption studies. New J Chem 40:3588-3596

Širić I, Kasap A, Bedeković D, Falandysz J (2017) Lead, cadmium and mercury contents and bioaccumulation potential of wild edible saprophytic and ectomycorrhizal mushrooms, Croatia. J Environ Sci Health Part B 52:156-165

Skibniewska A, Smoczyński S (1999) Wpływ obróbki kulinarnej na poziom radiocezu w grzybach. Roczn Państw Zakł Hig 50:157-162

Species Fungorum (2017) http://www.speciesfungorum.org/Names/ SynSpecies.asp?RecordID=212682; retrieved on February 4, 2017)

Svoboda L, Kalač P, Špička J, Janoušková D (2002) Leaching of cadmium, lead and mercury from fresh and differently preserved edible mushroom, Xerocomus badius, during soaking and boiling. Food Chem 79:41-45

Vetter J (2003) Chemical composition of fresh and conserved Agaricus bisporus mushroom. Z Lebensm Unters Forsch 217:10-12

Wang XM, Zhang J, Wu LH (2014) A mini-review of chemical composition and nutritional value of edible wild-grown mushroom from China. Food Chem 151:279-285

Zhang D, Frankowska A, Jarzyńska G, Kojta AK, Drewnowska M, Wydmańska D, Bielawski L, Wang J, Falandysz J (2010) Metals of King Bolete (Boletus edulis) collected at the same site over two years. African J Agric Res 5:3050-3055

Źrodlowski Z (1995) The influence of washing and peeling of mushrooms Agaricus bisporus on the level of heavy metal contamination. Polish J Food Nutr Sci 45:26-33 